Pécsi Tudományegyetem, Általános Orvostudományi Kar, Fogorvostudományi Szak, Fogpótlástani Tanszék* Smilesavers Dental USA, Sunnyvale, CA 94085, 1214 Apollo Way**

\title{
Temporomandibuláris ízületi rendellenesség gyakoriságának vizsgálata Parkinson-kóros páciensek esetében
}

\author{
Elözetes vizsgálat
}

\author{
DR. BAUMANN PETRA*, DR. MARADA GYULA*, JAHANI MARYAM**, DR. RADNAI MÁRTA*
}

\begin{abstract}
Parkinson-kórban a remegés és az izmok merevsége orofaciális fájdalmat, állkapocsízületi panaszokat is okozhat. Kutatásunk célja volt megvizsgálni, hogy Parkinson-kóros pácienseknél gyakrabban fordul-e elő állkapocsízületi rendellenesség. A vizsgálatban 13 Parkinson-kórral kezelt beteg vett részt, átlagéletkoruk $64,77 \pm 5,81$ év. A kontroll csoport tagjai a Pécsi Tudományegyetem Fogászati és Szájsebészeti Klinika Fogpótlástani Tanszékének páciensei közül kerültek ki, átlagéletkoruk 53,69 \pm 4,38 év $(n=13)$. A temporomandibuláris diszfunkció vizsgálatára a Helkimo-indexrendszert alkalmaztuk. Az anamnesztikus indexet vizsgálva megállapítható, hogy az Ai0 érték magasabb volt a kontrollcsoport esetén (kontroll: 76,92\%, Parkinsonos csoport: 61,54\%). A kontrollcsoport 30,77\%-a, a Parkinsonos csoport 15,38\%-a volt klinikailag tünetmentes. Enyhe diszfunkció mutatkozott a kontrollok $46,15 \%$ és a betegek $38,46 \%$-ban. A Parkinsonos csoport 46,15\%-ában tapasztaltunk közepes mértékű diszfunkciót, míg a kontrollcsoport esetén ez 23,08\%-ban fordult elő. Ugyan a vizsgálatban kevesen vettek részt, mégis alátámasztja azt a feltevést, hogy Parkinson-kórban szenvedőknél magasabb lehet a temporomandibuláris diszfunkció gyakorisága.
\end{abstract}

Kulcsszó: Parkinson-kór, Helkimo-index, temporomandibuláris ízületi diszfunkció

A Parkinson-kór progresszív neurodegeneratív betegség. Hátterében a basalis ganglionok károsodása áll, amihez a dopaminszint csökkenése társul [1]. Főbb tünetei: hypokinesia, bradykinesia (az akaratlagos mozgások csökkenése, lelassulása), az izmok merevsége, nyugalmi tremor (remegés) és járászavar. Az izomtónus fokozódása következtében a végtagokban hajlítás közben minden irányban ellenállás tapasztalható; a hát-, illetve törzsizmok merevsége miatt alakul ki a görnyedt testtartás. Parkinson-kórban az orofaciális régióban is jelentkezhetnek motoros rendellenességek. A hypokinesia az arcizmokat is érinti, ennek következtében az arc kifejezéstelenné válik, úgynevezett „pókerarc" alakul ki. A beszéd monotonná, hadaróvá válik [3, 4]. A betegség későbbi fázisában nyelési nehézség is előfordulhat [5]. A remegés és az izmok merevsége orofaciális fájdalmat, állkapocsízületi panaszokat is okozhat $[1,11]$. Egyes tanulmányok szerint a megváltozott testtartás az állkapocsízület biomechanikájában is változást okoz, hozzájárulva ezzel az ízületi rendellenességek megjelenéséhez [9], ugyanakkor az ízvápa és a fejecs viszonya is hatással lehet a fejtartásra [6]. Parkinson-kóros betegek temporomandibuláris (TM) ízületi érintettségével kevés vizsgálat foglalkozott. Kutatásunk célja volt megvizsgálni, hogy Parkinson-kóros pácienseknél gyakrabban fordul-e elő állkapocsízületi rendellenesség.

\section{Anyag és módszer}

A vizsgálatban 13 Parkinson-kór miatt kezelt beteg vett részt (4 férfi és 9 nő), átlagéletkoruk 64,77 $\pm 5,81$ év. A kontroll csoport tagjai a Pécsi Tudományegyetem Fogászati és Szájsebészeti Klinika Fogpótlástani Tanszékének páciensei közül kerültek ki (5 férfi és 8 nő), átlagéletkoruk 53,69 $\pm 4,38$ év ( $n=13)$.

A temporomandibuláris diszfunkció vizsgálatára a Helkimo-indexrendszert alkalmaztuk [7, 8]. A Helkimoindex anamnesztikus és klinikai diszfunkciós indexből áll. Az anamnesztikus indexet a vizsgált személyek kérdéseinkre adott szubjektív válaszai alapján határoztuk meg. A kérdések a panaszokra vonatkoztak, úgymint az állkapocs mozgása közben esetleg észlelt hangjelenség, korlátozott elmozdulások, fáradtságérzés a rágóizmokban, vagy ezekben és az ízület környékén észlelt fájdalom. Az anamnesztikus index háromfokozatú: AiO = panaszmentes, $\mathrm{Ail}=$ enyhe tünetek, Aill = súlyos tünetek.

A klinikai diszfunkciós index az állkapocs elmozdulásai, az állkapocsízület müködése, az állkapocsízület és a rágóizmok tapintása alapján határozható meg. A maximális szájnyitás mértéke: az alsó és a felső metszőfogak élének távolsága szájnyitáskor. A kapott értékhez hozzáadjuk a vertikális túlharapás mértékét. $A$ mérés vonalzóval vagy tolómérővel történik, az értékeket milli- 
méterben mérjük. Oldalmozgás vizsgálata: alsó és felső metszőfogakon függőleges jelzést húzunk interkuszpidációs helyzetben, majd jobb, illetve bal oldali kitérésnél mérjük a jelzések közti távolságot. A mandibula propulziós helyzetének vizsgálatához az alsó és felső szemfogon húzunk vertikális jelzést interkuszpidációs helyzetben, és az állkapocs elöretolt helyzetében mérjük a két vonal közötti távolságot [8].

\section{A vizsgálat eredményeinek értékelése}

Az elmozdulások értékelése:

Szájnyitás: $\geq 40 \mathrm{~mm}$, horizontális mozgás: $\geq 7 \mathrm{~mm}$ : 0 pont.

Kismértékben korlátozott szájnyitás: 30-39 mm, horizontális mozgások 4-6 mm: 1 pont.

Súlyosan korlátozott szájnyitás: $<30 \mathrm{~mm}$, horizontális mozgások < $4 \mathrm{~mm}$ : 5 pont.

Az állcsúcs oldalirányú kitérése: kitérés $<2 \mathrm{~mm}$, nincs hangjelenség: 0 pont.

Ha az állcsúcs kitérése a szájnyitás végén $\geq 2 \mathrm{~mm}$, és/vagy hangjelenség az ízületben: 1 pont.

Szájzár, vagy luxáció: 5 pont.

A kétoldali rágóizmok és ízület tapintásakor kapott eredmények értékelése:

Nincs érzékeny izom: 0 pont.

Fájdalom 1-3 tapintási helyen: 1 pont.

Fájdalom 4 vagy több tapintási helyen: 5 pont.

Állkapocsízület tapintása: a jobb és bal oldali ízületet egyszerre tapintva vizsgáljuk:

Nincs nyomásérzékenység: 0 pont.

Laterális irányú nyomásérzékenység: 1 pont.

Érzékenység dorzális irányú nyomásra: 5 pont.

Fájdalom értékelése:

Mandibula mozgásai közben jelentkező fájdalom vizsgálata (szájnyitás, összezárás, protrúzió, oldalmozgások).

Nincs fájdalom mozgás során: 0 pont.

Fájdalom valamelyik mozgásnál: 1 pont.

Fájdalom kettő vagy többirányú mozgásnál: 5 pont.

A vizsgálat végén a kapott pontszámok összege képezi a diszfunkciós pontszámot.

0 pont $=$ Di0 klinikailag panaszmentes

1-4 pont $=$ Dil enyhe diszfunkció

$5-9$ pont $=$ Dill közepes diszfunkció

10-25 pont $=$ Dilll súlyos diszfunkció $[7,8]$.

\section{Eredmények}

A vizsgált személyek életkor és nem szerinti megoszlását az 1. táblázat mutatja. Az anamnesztikus indexet vizsgálva (2. táblázat) megállapítható, hogy az Ai0 ér- ték magasabb volt a kontrollcsoport esetén (kontroll: 76,92\%, Parkinsonos csoport: $61,54 \%$ ). Egy esetben kaptunk Aill indexet; ez a kis esetszám miatt nem értelmezhető. Az összes vizsgált személy $69,23 \%$-a panaszmentes volt.

A klinikai vizsgálat alapján kapott Di komponensek (3. táblázat) azt mutatták, hogy a Parkinson-kóros csoportban gyakoribbak voltak az enyhe diszfunkciós tünetek, mint a kontrollcsoportban. A kontrollcsoport 30,77\%-a klinikailag tünetmentes volt, míg 46,15\%-a enyhe diszfunkciót mutatott. A Parkinsonos csoport 46,15\%-ánál volt mérhető közepes mértékủ diszfunkció, míg a kontrollcsoport esetén ez csak 23,08\%-ban fordult elő. A Parkinsonos csoport tagjainak csak $15,38 \%$-a volt tünetmentes; 38,46\%-ban enyhe diszfunkció jelentkezett. Súlyos diszfunkciót nem tapasztaltunk egy beteg esetében sem.

A csoportok között nem volt szignifikáns eltérés sem az anamnesztikus, sem a klinikai diszfunkciós indexben.

\section{Megbeszélés}

Bár a vizsgálatban kevesen vettek részt, mégis alátámasztja azt a feltevést, hogy Parkinson-kórban szenvedőknél magasabb lehet a temporomandibuláris ízületi diszfunkció gyakorisága, hiszen a klinikai vizsgálat 84,61\%-ukban mutatott enyhe vagy közepesen súlyos tüneteket annak ellenére, hogy a betegeknek csak kisebb része számolt be szubjektív panaszokról (Ail és Aill: $38,46 \%)$. Feltehetően az alapbetegség egyéb, fontosabb tünetei el is fedik az állkapocsízület érintettségét.

Az előzetes vizsgálat másik hibája lehet az életkori eltérés a Parkinson-kóros és ebben a betegségben nem szenvedők között; a kontrollcsoport tagjai valamivel fiatalabbak voltak. A további vizsgálatokban az életkornak azonosnak, vagy legalább hasonlónak kell lennie a két csoportban a megalapozottabb következtetések levonása érdekében, hiszen az idősebb életkor is lehet oka az ízület elváltozásainak [10].

Bakke és munkatársai szerint Parkinson-kóros pácienseknél az orofaciális régióban jelentkező motoros rendellenességek hatással lehetnek a temporomandibuláris ízületi rendellenességek kialakulására, bár nem találtak szignifikáns összefüggést a motoros funkció károsodása és az ízületi rendellenesség előfordulása között [1]. Da Costa Silva és munkatársai 59 Parkinson-kóros egyénen végzett vizsgálatukban 20,33\%-ban találtak TM ízületi rendellenességet [2], ami lényegesen kisebb gyakoriság, mint az általunk kapott eredmény.

Felvetett kérdésünkre, miszerint Parkinson-kórban szenvedő betegeknél az állkapocsízületben gyakrabban fordul elő rendellenesség, ilyen kis létszámú beteg adatainak elemzése alapján nem adható biztos válasz, ehhez további vizsgálatok szükségesek. 
A vizsgált csoportok életkor és nem szerinti megoszlása

\begin{tabular}{|c|c|c|c|c|c|c|c|c|c|c|}
\hline \multirow{2}{*}{$\begin{array}{l}\text { Életkor } \\
\text { kategóriák }\end{array}$} & \multicolumn{2}{|c|}{$\begin{array}{l}\text { Parkinson- } \\
\text { kóros } \\
\text { csoport }\end{array}$} & \multicolumn{2}{|c|}{ Kontroll } & \multicolumn{2}{|c|}{$\begin{array}{l}\text { Összes } \\
\text { vizsgált } \\
\text { személy }\end{array}$} & \multirow[t]{2}{*}{ Nem } & \multirow{2}{*}{\begin{tabular}{|c}
$\begin{array}{c}\text { Parkinson- } \\
\text { kóros } \\
\text { csoport }\end{array}$ \\
$\begin{array}{c}\text { elemszám } \\
\text { (fő) }\end{array}$
\end{tabular}} & \multirow{2}{*}{\begin{tabular}{|c|} 
Kontroll \\
$\begin{array}{c}\text { elemszám } \\
\text { (fő) }\end{array}$ \\
\end{tabular}} & \multirow{2}{*}{\begin{tabular}{|c}
$\begin{array}{c}\text { Összes } \\
\text { vizsgált } \\
\text { személy }\end{array}$ \\
$\begin{array}{c}\text { elemszám } \\
\text { (fő) }\end{array}$
\end{tabular}} \\
\hline & $\begin{array}{c}\text { elemszám } \\
\text { (fö) }\end{array}$ & $\begin{array}{c}\text { megoszlás } \\
(\%)\end{array}$ & $\begin{array}{l}\text { elemszám } \\
\text { (fö) }\end{array}$ & $\begin{array}{c}\text { megoszlás } \\
(\%)\end{array}$ & $\begin{array}{c}\text { elemszám } \\
\text { (fő) }\end{array}$ & $\begin{array}{c}\text { megoszlás } \\
(\%)\end{array}$ & & & & \\
\hline $40-59$ & 1 & 7,69 & 10 & 76,92 & 11 & 42,31 & Férfi & 4 & 5 & $\begin{array}{l}9 \\
\end{array}$ \\
\hline $60-82$ & 12 & 92,31 & 3 & 23,08 & 15 & 57,69 & Nő & 9 & 8 & 17 \\
\hline Összesen & 13 & 100 & 13 & 100 & 26 & 100 & Összesen & 13 & 13 & 26 \\
\hline
\end{tabular}

2. táblázat

Anamnesztikus indexek a Parkinson-kóros és a kontrollcsoportban

\begin{tabular}{|l|c|c|c|c|c|c|}
\hline \multirow{2}{*}{ Anamnesztikus index } & \multicolumn{2}{|c|}{ Parkinson-kóros csoport } & \multicolumn{2}{c|}{ Kontroll } & \multicolumn{3}{c|}{ Összes vizsgált személy } \\
\cline { 2 - 8 } & elemszám (fö) & megoszlás (\%) & elemszám (fö) & megoszlás (\%) & \multirow{2}{*}{ elemszám (fő) } & megoszlás (\%) \\
\hline Ai0 & 8 & 61,54 & 10 & 76,92 & 18 & 69,23 \\
\hline Ail & 4 & 30,77 & 3 & 23,08 & 7 & 26,92 \\
\hline Aill & 1 & 7,69 & 0 & 0,00 & 1 & 3,85 \\
\hline Összesen & 13 & 100 & 13 & 100 & 26 & 100 \\
\hline
\end{tabular}

Diszfunkciós indexek a Parkinson-kóros és a kontrollcsoportban

\begin{tabular}{|l|c|c|c|c|c|c|}
\hline \multirow{2}{*}{ Diszfunkciós index } & \multicolumn{2}{|c|}{ Parkinson-kóros csoport } & \multicolumn{2}{c|}{ Kontroll } & \multicolumn{2}{c|}{ Összes vizsgált személy } \\
\cline { 2 - 8 } & elemszám (fö) & megoszlás (\%) & elemszám (fö) & megoszlás (\%) & elemszám (fő) & megoszlás (\%) \\
\hline Di0 & 2 & 15,38 & 4 & 30,77 & 6 & 23,08 \\
\hline Dil & 5 & 38,46 & 6 & 46,15 & 11 & 42,31 \\
\hline Dill & 6 & 46,15 & 3 & 23,08 & 9 & 34,62 \\
\hline Dilll & 0 & 0,00 & 0 & 0,00 & 0 & 0,00 \\
\hline Összesen & 13 & 100 & 13 & 100 & 26 & 100 \\
\hline
\end{tabular}

Anyagi támogatás: A vizsgálat nem részesült anyagi támogatásban.

\section{Szerzói munkamegosztás:}

BaUMANn P: a kézirat megszövegezése

MARADA GY: a vizsgálatok megszervezése

JAHANI M: a vizsgálatok kivitelezése

RADNAI M: a vizsgálatok megtervezése

Érdekeltségek: A szerzőknek nincsenek érdekeltségeik.

\section{Irodalom}

1. Bakke M, Larsen SL, Lantrup $C$, Karlsborg M: Orofacial function and oral health in patients with Parkinson's disease. Eur J Oral Sci 2011; 119: 27-32.

2. Da Costa Silva PF, Biasotto-Gonzalez DA, Motta JL, Silva SM, FerRari MAR, Fernandes SPK, et al.: Impact in oral health and the prevalence of temporomandibular disorders in individuals with Parkinson's disease. J Phys Ther Sci 2015; 887-891.

3. Friedlander A, Mahler M, Norman KM, Ettinger Rl: Parkinson disease: Systematic and orofacial manifestations, medical and dental management. JADA 2009; 140. (6): 658-669.
4. Robertson LT, Hammerstad JP: Jaw movement dysfunction related to Parkinson's disease and partialy modified by levodopa. J Neurol Neurosurg Psychiatry 1996; 60: 41-50.

5. Nakayama $Y$, Washio M, Mori M: Oral health conditions in patients with Parkinson's disease. J Epidemiol 2004; 14: 143-150.

6. Olmos SR, Kritz-Silveristein D, Halligan W, Silverstein ST: The effect of condyle fossa relationships on head posture. Cranio 2005; 23: 48-52.

7. Rani S, Pawah S, Gola S, BaKshi M: Analysis of Helkimo index for temporomandibular disorder diagnosis in the dental students of Faridabad city: A cross-sectional study. J Indian Prosthodont Soc 2017; 17: 48-52.

8. SzentPÉTERY A, FazeKAS A, RudAs K: Standardizált módszer a funkcionális állkapocsízületi betegség epidemiológiai és klinikai vizsgálatára. Fogorv Szle 1986; 79: 21-25.

9. Tingey EM, Buschang PH, Throckmorton GS: Mandibular rest position influenced by head support and body posture. Am J Orthod Dentofacial Orthop 2001; 120: 614-622.

10. Vo N, Niedernhofer LJ, Nasto LA, Jacobs L, Robbins PD, Kang J, Evans $\mathrm{CH}$ : An overview of underlying causes and animal models for the study of age-related degenerative disorders of the spine and synovial joints. J Orthop Res. 2013; 31: 831-837.

11. Zlotnik Y, Balash Y, Korczyn AD, Giladi N, GuREVICH T: Disorders of the oral cavity in Parkinson's disease and Parkinsonian Syndromes. Parkinsons Dis 2015, Article ID 379482. 
Baumann P, Jahani M, Marada Gy, Radnai M

\section{Frequency of temporomandibular joint disorder in patients with Parkinson's disease Pilot study}

In Parkinson's disease the involuntary movements, tremor and the rigidity of the muscles may result in orofacial pain or temporomandibular joint disorder. The aim of our study was to examine if temporomandibular (TM) dysfunction occurs more often in these patients than in healthy subjects. 13 patients treated for Parkinson's disease belonged to the case group; average age was $64,77 \pm 5,81$. Controls were selected from the out-patients of the Prosthetic Department/University of Pécs/Hungary ( $n=13$, average age: $53,69 \pm 4,38)$. The Helkimo index was used for the assessment of the TM dysfunction. According to the anamnestic component the AiO was higher in case of the control group (control group: $76,92 \%$, Parkinson group: $61,54 \%$ ). $30,77 \%$ of the control group and $15,38 \%$ of the Parkinson group had no clinical sign of TM dysfunction. Mild dysfunction was found in $46,15 \%$ of the controls and $38,5 \%$ of the Parkinson's patients. Moderate symptoms (Dill) were found in $46,15 \%$ in the Parkinson patients' group, while it occurred only $23,08 \%$ among the controls. Although a small number of patients participated in the in the pilot study, the results support the hypotheses that TM dysfunction may occur more frequently among patients with Parkinson disease.

Keywords: Helkimo index, Parkinson's disease, temporomandibular joint disorder 